\title{
Microbial and Chemical Evaluation of broiler's skin as co-product incorporated in meat industry
}

\author{
Gehan M. Kassem', Fatma H. M. Ali', M. M. Farag ${ }^{3}$ \\ ${ }^{1}$ Department of Food Hygiene and Control Faculty of Veterinary Medicine Cairo University, Giza, Egypt \\ ${ }^{2}$ Department of Food Hygiene and Control Faculty of Veterinary Medicine Beni-Suef University, Beni-Suef, Egypt \\ ${ }^{3}$ Department of Biochemistry Faculty of Agriculture Cairo University, Giza, Egypt
}

\begin{abstract}
Thirty samples of freshly slaughtered broiler frame with skin were obtained from small scale poultry processing plant in Cairo and Giza markets. Samples of neck and breast skin were examined for Total colony count, Psychrotrophic count, Staphylococcus aureus count, Coliform Count, presumptive $E$. coli count and total yeast and mould count. In addition isolation of Salmonella spp. and thermotolerant Campylobater were performed. Lower bacterial counts were recorded in cooked samples, with mean value of $7.6 \pm 0.18,5.68 \pm 0.16,5.12 \pm 0.14,3.6 \pm 0.3,2.3 \pm 0.39$ and $6.85 \pm 0.37 \log 10 \mathrm{cfu} / \mathrm{g}$ in raw samples and $0.91 \pm 0.27,0.74 \pm 0.21,0.56 \pm 0.19,1.1 \pm$ $0.13,<3$ and $2.44 \pm 0.12 \log 10 \mathrm{cfu} / \mathrm{g}$ in cooked samples respectively. The incidence of $S$. aureus, Salmonella and Campylobater jejuni in raw skin samples were $66.7 \%, 20 \%$, and $56.6 \%$, respectively. While $S$. aureus was unexpectedly isolated from cooked samples. Fat content was estimated by using Sohexelt method and fatty acids content of methylester were determined.

Keywords: broiler's skin, Campylobacter, fatty acid profile, microbial evaluation Salmonella, $S$. aureus
\end{abstract}

Poultry has become an important food supply allover the world and growing consumption of chicken increasingly has been varied. Nowadays, consumer habits have changed; most poultry is sold as portioned or further processed, rather than as whole birds. This change in consumer preference has resulted in the poultry processing industry generating ever increasing amount of under utilized co-products. Chicken skin in particular, accumulates in huge quantities. Most of excess skin was generally combined with other waste to produce poultry by-products meal of various qualities, meanwhile a small proportion is used in meat emulsion or used as source of fat (Cliche et al., 2003). Poultry skin contains the most calories as the chicken meat is low in calories so health conscious consumers should avoid skin as all most recent medical advice has reinforced the importance of reducing fat, eating a balanced diet in order to bring down the instances of heart diseases and obesity (British poultry council, 2001).

The bacterial load of chicken skin is investigated by Emara and Nouman (2002), Buhr et al. (2003) and Abd-El Wahab (2005) they found that total colony count, Coliform count, $S$. aureus count and E. coli count were $10^{4}-10^{9}, 3 \times 10^{3}$ $6 \times 10^{3}, 10^{3}, 7 \times 10-7 \times 10^{2}$ cfu $/ g$ respectively. Bacterial contamination of external surfaces of processed poultry carcasses can originate from contact with ingesta or feces excreted from alimentary tract during growing out, transportation, or processing (Byrd et al.,1998 and Berrang et al., 2002). Moreover, empty feather follicles harbor bacteria making complete removal of bacteria difficult if not impossible (Nacomcf, 1997).

The presence of Campylobacter in commercial broiler flocks and processed poultry has been widely demonstrated (Jacobs-Rietsma, 2000) as Campylobacter cells adhering to the skin were located primarily on rough areas of chicken skin, in crevices or entrapped inside deep channels and feather follicles with water provide a micro environment suitable for their survival (Lee et al.,1998 and Chantarapanont et al., 2003). Meanwhile, Waldroup (1996) and Jeffry et al. (2001) reported that Campylobacter incidence in poultry carcasses vary considerably ranged from $30-100 \%$, while that of Salmonellae is ranged 
from $30-50 \%$. The incidence of Salmonellae and Campylobacter in raw poultry carcasses are greatly affected by the operation condition of scalding process. High scalding temperature greatly reduced bacterial survival in the scalders, while cause the broiler skin to lose more of the stratum cornium layer and making the skin easier for bacteria to adhere during defeathering and evisceration (Oosterom et al., 1983, Yang et al., 2001 and Alter et al., 2005). It is noteworthy mention that the numbers of reported cases of Campylobacteriosis increased rapidly in most countries. It is now recognized as a more common enteric pathogen than Salmonellae in several countries, developed as well as developing Berndtson (1996). In adequately cooked poultry and poultry products are the most common source for epidemic and sporadic food borne cases.

Recently, poultry skin is incorporated in the formulation of most meat and poultry products which constitutes a major concern facing meat industry. Therefore, the current study was under taken with the objective of evaluating microbiological condition of marketed broiler's skin, determined of their fat and fatty acid content as well as studying the effect of heat treatment on skin quality.

\section{Material and Methods}

Samples. Thirty samples of freshly slaughtered broiler's frame with skin were purchased from small scale poultry processing plants in Cairo and Giza markets, and transported to the laboratory in an ice-box. Skin samples from neck and breast were used for microbiological investigation According to (Kotula and Davis, 1999), while whole skin was used for chemical analysis. Each sample was divided into two portions; the first was used as raw samples while the other part was cooked in boiling water bath for $30 \mathrm{~min}$. as cooked sample, according to (Emara and Nouman, 2002). Microbiological examination. Ten grams from each sample were homogenized with $90 \mathrm{ml}$ Ringer's solution for one minute to provide a dilution of $10^{-1}$. Ten fold decimal dilutions up to $10^{-8}$ were performed from the original dilution. Decimal dilutions of raw and cooked samples were examined for Total colony count (ISO 1991), Psychrotrophic count (APHA 1992), Staphylococcus aureus count (ISO 1995), Coli-form counts (MPN) (ISO 1994 and De Man 1983), presumptive E. coli count (MPN) (ISO 1994 and De Man 1983) and total yeast and mould count (APHA, 1992). As well as isolation and identification of Salmonella (ISO, 1993 and Kauffmann, 1974) and thermotolerant Campylo-bacter (ISO 1994).

\section{Chemical analysis.}

Fat content. It was determined according to (AOAC, 1990) by using Soxhlet method. While the fatty acids profile was performed by fat extracted according to (Folch et al., 1957) and the methylester of fatty acids was prepared according to the method recommended by (Vogel, 1975). Analysis was performed in triplicate and reported on dry weight basis.

Table (1): Microbial load $\log _{10} \mathrm{cfu} / \mathrm{g}$ of raw and cooked broiler's skin samples.

\begin{tabular}{|c|c|c|c|c|c|c|c|c|}
\hline \multirow{2}{*}{$\begin{array}{l}\text { Bacterial } \\
\text { Groups }\end{array}$} & \multicolumn{4}{|c|}{ Raw } & \multicolumn{4}{|c|}{ Cooked } \\
\hline & Max. & Min. & Mean & $\pm \mathbf{S E}$ & Max. & Min. & Mean & $\pm \mathbf{S E}$ \\
\hline TCC & 9.47 & 6.0 & 7.6 & 0.18 & 3.3 & $<10^{2}$ & 0.91 & 0.27 \\
\hline Psych C* & 7.0 & 4.32 & 5.68 & 0.16 & 2.89 & $<10^{2}$ & 0.74 & 0.21 \\
\hline S. aureus C & 6.32 & 3.43 & 5.12 & 0.14 & 2.68 & $<10^{2}$ & 0.56 & 0.19 \\
\hline Coliform C & 4.2 & 1.9 & 3.6 & 0.30 & 1.4 & $<3$ & 1.1 & 0.13 \\
\hline $\begin{array}{l}\text { Presumptive } \\
\text { E. coli C }\end{array}$ & 2.7 & $<3$ & 2.3 & 0.39 & $<3$ & $<3$ & $<3$ & --- \\
\hline $\begin{array}{l}\text { Total Yeast and } \\
\text { Mould C }\end{array}$ & 10.56 & 3.95 & 6.85 & 0.37 & 3.36 & 1.48 & 2.44 & 0.12 \\
\hline
\end{tabular}

${ }^{*} \mathrm{C}=$ count. 
Table (2): Potential food poisoning bacteria in raw and cooked broiler's skin samples.

\begin{tabular}{lcccc}
\cline { 2 - 5 } \multicolumn{1}{c}{ Isolated microorganism } & \multicolumn{2}{c}{ Raw } & \multicolumn{2}{c}{ Cooked } \\
\cline { 2 - 5 } & No. of positive & $\%$ & No. of positive & $\%$ \\
\cline { 2 - 5 } S. aureus (Coagulase +ve) & 20 & 66.7 & 7 & 23.3 \\
Presumptive E. coli & 16 & 53.3 & - & - \\
Campylobacter $(C$. jejuni) & 17 & 56.6 & - & - \\
Salmonella spp & 6 & 20 & & - \\
\hline
\end{tabular}
$\mathrm{N}=30$

Table (3): Serotypes of isolated salmonella strain.

\begin{tabular}{lccc} 
& Serotype & No. & $\%$ \\
\hline S. enteritidis $O: 1$ & 2 & 6.66 \\
S. london $O: 3$ & 2 & 6.66 \\
S. typhimurium $O: 4$ & 1 & 3.33 \\
S. kentucky $O: 8$ & 1 & 3.33 \\
\hline
\end{tabular}

$$
\mathrm{N}=30
$$

Table (4): Fatty acid Profile and fat content of raw and cooked broiler's skin.

\begin{tabular}{lcc}
\hline \multicolumn{1}{c}{ Fatty acid } & \multicolumn{2}{c}{ Fatty acid \% of total Fatty Acids } \\
\cline { 2 - 3 } & Raw & Cooked \\
\hline Capric acid C10:0 & 0.036 & 0.15 \\
Lauric acid C 12:0 & 0.047 & 0.28 \\
Myristic acid C 14:0 & 0.54 & 0.53 \\
Myristoleic acid C 14:1 & 2.46 & 5.9 \\
Palmitic acid C 16:0 & 22.09 & 28.84 \\
Palmitoleic acid C 16:1 & 6.61 & 7.59 \\
Stearic acid C 18:0 & 9.722 & 6.84 \\
Oleic acid C 18:1 & 39.30 & 44.59 \\
Linoleic acid C 18:2 & 18.75 & 7.25 \\
Linolenic acid C 18:3 & 1.02 & 0.27 \\
Unidentified & 0.37 & 0.79 \\
*SUM SAT & 33.087 & 37.61 \\
SUM MONO & 48.37 & 58.08 \\
SUM PUFA & 19.77 & 7.52 \\
Ratio UNSAT/SAT & 2.05 & 1.74 \\
FSat content & $36.6 / 100 \mathrm{~g}$ & $19.3 / 100 \mathrm{~g}$ \\
\hline$*$ SUM= & & \\
\hline
\end{tabular}




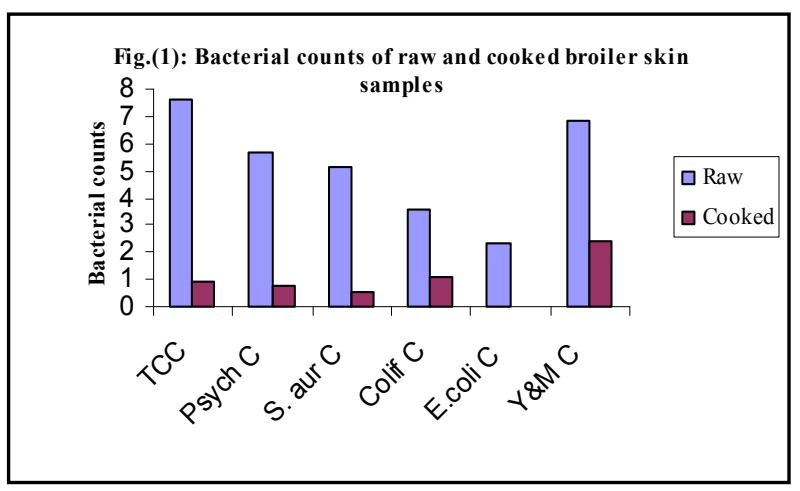

\section{Results and Discussion}

The different bacterial counts data were converted to $\log _{10} \mathrm{cfu} / \mathrm{g}$ of skin before estimation of maximum, minimum, mean and standard error. The data present in Table (1) and Fig. (1) showed that mean count of Total colony count (TCC), Psychrotrophic bacteria (Psych.), Staphylococcus aureus (S. aureus), Coliform (MPN), presumptive E. coli (MPN) and Total yeast and mould were 7.6 $\pm 0.18,5.68 \pm 0.16,5.12 \pm 0.14,3.6 \pm 0.3,2.3 \pm$ 0.39 and $6.85 \pm 0.37 \log 10 \mathrm{cfu} / \mathrm{g}$ for raw samples respectively. Generally, yeast and mould contents are neglected in quality investigation of poultry and poultry products, although their count of examined skin samples were high and couldn't be eliminated by heat treatment, which may constitute an unavoidable source of contamination to meat and poultry products. Bryan (1990) stated that yeast and mould have been isolated from air, soil of poultry brooding houses, wet feed and bird droppings, in addition yeasts and moulds have been isolated from feathers, feed and bodies of the birds during the time of slaughter.

The given results proved that chicken skin is a major source of carcass contamination. Similar results were recorded by (Berrang et al., 2001; Chantarapanont et al., 2003); Goksoy et al., 2004 and Ali and Ouf, 2005). While lower results were recorded by (Buhr et al., 2000). It could be referred to the bad sanitary condition and unhygienic practices in the small poultry processing plants from which examined samples were purchased. Moreover, differences in samples collection, size, technique used and culture methods may account for the variability of results between studies.

The present situation may reflect an important problem where these plants are the main supply of

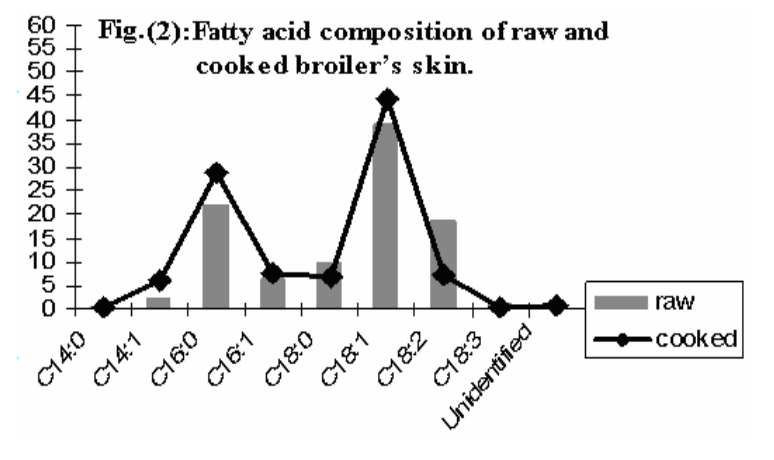

poultry and poultry skin to meat products processing factories and fast food establishments which may constitute a public health hazard.

Cooking of the skin samples in boiling water bath for thirty minutes reduced the bacterial recovery of TCC, Psych C, S. aureus C, Coliform C, presumptive E. coli $\mathrm{C}$ and total yeast and mould $\mathrm{C}$ by $6.69,4.94,4.56,2.5,2.3$ and $2.44 \log 10 \mathrm{cfu} / \mathrm{g}$ respectively. Nearly similar results were recorded by Emara and Nouman (2002). The same authors found that an increase in TCC by $2-4 \log 10 \mathrm{cfu} / \mathrm{g}$ and higher incidence of Salmonella when raw avian skin is added to luncheon and beef burger formulation. Also addition of cooked skin lead to an increase in TCC, but Salmonella could not be detected.

The prevalence of Coliform, faecal Coliform and presumptive $E$. coli was 100,100 and $53.3 \%$ from examined samples respectively. These results in harmony with that obtained by Buhr et al. (2003). In this respect Dickens and Whitetemore (1997) found that artificial contamination of picken fingers with $E$. coli on one chicken lead to contamination of the following 50th poultry during picking. Meanwhile Kotulu and Pandya (1995) and Buhr et al. (2000) reported that broiler carcasses with feaces soiled feather and skin had high levels of Coliform, and E. coli than carcasses wit clear feather prior to scalding and picking. Salmonella was isolated from raw samples at rate of $20 \%$ of examined samples was positive as shown in (Table 2). The biochemical and serological identification of isolated strain (table 3) revealed that $6.66 \%$ was Salmonella enteritidis O: 1, 6.66\% was Salmonella london O: 3, 3.33\% Salmonella typhimurium O: 4 , and $3.33 \%$ was Salmonella kentucky O: 8. Similar result obtained by (Waldroup, 1996; Jeffrey et al., 2001 and 
Jorgensen et al., 2002). Higher results were recorded by Yang et al. (2001).

The incidence of thermotolerant Campylobacter and $C$. jejuni in examined broiler skin was $73.3 \%$ and $56.6 \%$ respectively. The high prevalence of Campylobacter species in broiler skin samples found in this study agreed with data reported by (Kotula and Pandya 1995; Brendtson et al., 1996; Waldroup, 1996; Achen et al., 1998; Kramer et al., 2000; Harrison et al., 2001; Jeffrey et al., 2001 and Abd-El Wahab, 2005). In this regard Stern and Robach (2003) suggested that Campylobacter levels found on the broiler carcasses might represent an important source of consumer exposure and potential risk for infection.

High level of enteric bacteria detected in broiler skin may be derived from the cloaca during picking or due to rupture of the intestinal tract during evisceration and contaminates the carcass (Berrang and Dickens 2000). On the other hand Murphy et al. (2001) proved that Salmonella survive longer in the chicken patties cooked under low humidity condition than high humidity, moreover, prolonged storage time and temperature increased incidence of Salmonella in cooked chicken patties.

Unexpectedly, $S$. aureus was isolated from steamed skin samples with incidence of $23.3 \%$. Whereas, no $E$. coli, Campylobacter and Salmonellae could be detected in cooked skin samples, as recorded by Emara and Nouman (2002).

The results obtained in (Table 4) showed high fat content 36.6 and $19.3 \%$ in raw and cooked broiler skin samples respectively. Similar results were recorded by Paul and Southgate (1978), Bonifer and Froning (1996), British poultry council (2001) and Cliché et al. (2003). It is noteworthy mentioned that heat treatment of skin samples reduced their fat content by about $50 \%$. Fatty acids (FA) composition of examined raw and cooked broiler skin samples are illustrated in (Table 4) and Fig (2). The present data revealed that total monounsaturated fatty acids (MUFA) constituted the highest percentage (48.37 \& $58.08 \%$ ) of total FA, followed by total saturated fatty acids (SFA) 33.087 and $37.61 \%$ for raw and cooked samples respectively. Polyunsaturated fatty acids (PUFA) showed the lowest percentage $(19.77 \& 7.52 \%)$ of total FA, these decreases in PUFA content in cooked samples appeared to be mainly due to change in linoleic acid. Major FA in broiler skin are Oleic acid C 18:1, Palmitic acid C 16:0, Linoleic acid C 18:2, Stearic acid C 18:0, Palmitoleic acid C 16:1. While Palmitic acid, Oleic acid and Linoleic acid were the dominating FA in the examined samples. The obtained results are in harmony with that recorded by Myers and Harris (1975) and Souza et al. (1999).

\section{Conclusion and recommendations}

It could be concluded that fat content of broiler skin is reduces to about $50 \%$ after cooking and is less saturated than that found in red meat. It supplies better proportion of monosaturated fatty acids and poylsaturated fatty acids which helps to reduce blood cholesterol level and also help the maintenance of healthy heart. Poultry skin contains most fatty tissues on poultry carcass. However, broiler's skin is considered as a major source of contamination with pathogenic as well as nonpathogenic bacteria. Cooking by ordinary methods could reduce but not eliminate all bacterial contamination. Hormonal and other residues may also be present. So use of skin as fat source in meat products may consider as bacterial and chemical risk factors especially in meat products don't processed at high temperature and during bad storage conditions. Recently poultry skin produced in recent days may be used in other industries, such as fat extraction and collagen extraction with advantages of low antigenicity to avian collagen.

\section{Acknowledgment}

The authors would like to seat deeply the sincere appreciation to Prof. Dr. Nagah M Hafez the former director of the regional center for safety and quality of foodstuffs (2000-2004) for the conduction of this work in the laboratory of the center.

\section{References}

Abd-El Wahab, M. A. (2005): Bacteriological risk assessment of processed broilers. M.V.Sc. Thesis, Fac. Vet. Med. Cairo Univ., Beni-Suef, Egypt

Ali, F. H. M. and Ouf, J. M. (2005): Evaluation of hygienic status of broiler parts with and without skin in retail markets in Egypt. Egypt. Vet. Med. Assoc., 53 (2): 611.

Alter, T.; Gaull, F.; Froeb, A. and Fehlhaber, K. (2005): Distribution of Campylobacter jejuni strains at different stages of a turkey slaughter line. Food Microbiol., 22: 345.

Achen, M.; Morishita, T. Y. and Cley, E. (1998): Shedding and colonization of Campylobacter jejuni in broilers from day of hatch to slaughter age. Avian Dis. 42:732.

AOAC (1990): Official Methods of Analysis. The Association official analytical chemists, $15^{\text {th }}$ ed. Virginia, USAAPFC: 282. 
APHA (1992): Compendium of Methods for the Microbial Examination of food. $3^{\text {rd }}$ Ed., American public health association, Washington, Dc., USA.

Berndtson, E. (1996): An overview of Campylobacter. Food associated pathogens, Uppsala, Sweden.

Berrang, M. E. and Dickens, J. A. (2000): Presence and level of Campylobacter on broiler carcasses through out the processing plant. J. Appl. Poult. Res., 9: 43.

Berrang, M. E.; Ladelt, S. R. and Buhr, R. J. (2001): Presence and level of Campylobacter,coliforms, Escherichia coli and Total Aerobic bacteria recovered from broiler parts with and without skin. J. Food. Prot., 64 (2): 184.

Berrang, M. E.; Buhr, R. J.; Cason, J. A. and Dickens, J. A. (2002): Microbiological consequences of skin removal prior to evisceration of broiler carcasses. Poult. Sci., 81: 134. Bonifer, L. B. and Froning, G. W. (1996): Chicken skin composition as affected by aqueous washing. J. Food Sci.., 61(5): 895

British Poultry council (2001): The voice of poultry meat producers.

Bryan F.L. (1990): Poultry and poultry meat products. In. Microbiol. Ecology of Food. Food commodities, J. H. silliker Ed. Academic press, London, pp.410.

Buhr, R. J.; Cason, J. A.; Dickens, J. A.; Hinton, A. and Ingram, K. D. (2000): Influence of flooring type during transport and holding on bacterial recovery from broiler carcass rinses before and after defeathering. Poult. Sci., 79: 436.

Buhr, R. J.; Berrang, M. E. and Cason, J. A (2003): Bacterial recovery from breast skin of genetically feathered and featherless broiler carcasses immediately following scalding and picking. Poult. Sci., 82: 1641.

Byrd, J. A. D. E.; Hume, M. E. C.; Bailey, R. H.; Stanker, L. H. and Hargis, B. (1998): Incidence of campylobacter in crops of preharvest market age broiler chickens. Poult. Sci., 77: 1303 .

Chantarapanont, W.; Berrang, M. And Joseph, F. F. (2003): Direct microscopic observation and viability determination of Campylobacter jejuni on chicken skin. J. Food. Prot., 66 (12): 2222.

Cliche, S.; Amiot, J. T.; Avezard, C.; and Gariepy, C. (2003): Extraction and characterization of collagen with and without telopeptides from chicken skin. Poult. Sci., 82: 503.

De Man, J. C. (1983): The probability of most probable number. Eur. J. Appl. Microbiol. Biotechnol., 17: 301.

Dickens, J. A. and Whitetemore, A. D (1997): Effect of acetic acid and hydrogen peroxide application during defeathering on microbiological quality of broiler carcasses prior to evisceration. Poult. Sci., 76: 657.

Emara, M. M. T. and Nouman, T. M. (2002): Detection of avian skin in meat products and its impact on quality. Egypt. Vet. Med. Assoc., 62 (6c): 147.

Folch, J. M.; Lees, S and Stanely, G. H. S. (1957): A simple method for isolation and purification of total lipids from animal tissues. J. Biol. Chem. 226: 497.

Goksoy, E. Ö.; Sirkan, S. and Kok, F. (2004): Microbiological quality of broiler carcasses during processing in two slaughterhouse in Turkey. Poult. Sci., 83: 1427.

Harrison, W. A.; Griffith, C. J.; Tennant, D. and Peters, A. C. (2001): Incidence of Campylobacter and Salmonellae isolated from retail chicken and associated packaging in South Wales. Letters in Appl. Microbiol., 33: 450.

International Standard Organization ISO 4883 (1991): Enumeration of microorganisms-colony count technique at 30 ${ }^{\circ} \mathrm{C}$.

International Standard Organization ISO 6579 (1993E): General guidance on methods for the detection of Salmonellae.

International Standard Organization ISO/ DIS 3811 (1994): Detection and enumeration of Coliform bacteria. International Standard Organization ISO/ DIS 10272 (1994): General guidance for detection of thermotolelerant Campylobacter.

International Standard Organization: ISO/ DIS 11866-1.2 (1994): General guidance for enumeration of presumptive Escherichia coli - Most probable number technique.

International Standard Organization ISO/ CD 6888-1 (1995): Microbiology of food and animal feeding stuffshorizontal method for the enumeration of coagulase positive Staphylococci (Staphylococcus aureus and other species) by colony count technique at $35-37^{\circ} \mathrm{C}$, Part1: Technique with confirmation of colonies.

Jacobs-Rietsma, W. (2000): Campylobacter in the food supply.P467 in Campylobacter. $2^{\text {nd }}$ ed. Nachamkin, I. and Blaser, M.J. ed. Am. Soc. Microbiol. press, Washington, DC. Jeffery, J. S.; Tonooka, K. H. and Lozanot, J. (2001): Prevalence of Campylobacter spp. From skin, crop, and intestine of commercial broiler chicken carcasses at processing. Poult. Sci., 80: 1390.

Jorgensen, F.; Bailey, R.; Williams, S.; Henderson, P.; Wareing, D. R.; Bolton, F. J. ; Frost, J. A.; Ward, L. and Humphrey T. J. (2002): prevalence and numbers of Salmonellae and Campylobacter spp. on whole chickens in relation to sampling methods. Int. J. Food Microbiol., 76 (12): 151 .

Kauffmann, F.L. (1974): Kauffmann white scheme. WHOBD / 172, L, REV.I. Acta Pathol. Microbiol., Scand, 61: 385.

Kotula, K. L. and Pandya, Y. (1995): Bacterial contamination of broiler chickens before scalding. J. Food. Prot., 58 (12): 1326.

Kotula, K. L. and Davis, M.E. (1999): Broiler skin sampling for optimum recovery of Salmonella spp. J Food Prot., 62(3): 284.

Kramer, J. M.; Frost, J. A.; Bolton, F. J. and Wareing, D. R. (2000): Campylobacter contamination or raw meat and poultry at retail sale: identification of multiple types and comparison with isolates from human infection. J. Food. Prot., 63 (12): 1654.

Lee, A.; Smith, S. C.; and Coloe, P. J. (1998): Survival and growth of Campylobacter jejuni after artificial inoculation onto chicken skin as a function of temperature and package conditions. J. Food. Prot., 61:1609.

Murphy, R. Y.; Johnson, E. R.; Marcy, J. A. and Johnson, M.G. (2001): Survival and growth of Salmonella and Listeria in chicken breast patties subjected to time and temperature abuse under varying conditions. J Food Prot., 64(1): 23.

Myers, S. J and Harris, N.D. (1975): Effect of electronic cooking on fatty acids in meats. J Am Diet Assoc., 67(3): 232. NACOMCF (National Advisory Committee on Microbiology Criteria for Food) (1997): Generic HACCP application in broiler slaughter house and processing. J. Food. Prot., 60: 579. 
Oosterom, J.; Notermans, S.; Karman, H. and Engles, G. B. (1983): Origin and prevalence of Campylobacter jejuni in poultry processing. J. Food Prot., 46: 339.

Paul, A. A. and Southgate, D. A. T. (1978): The composition of foods, London: HMSO.

Souza, S. A.; Visentainer, J. V.; Matsushita, M. and Souza, N. E. (1999): Lipids and fatty acids in roasted chickens. Arch. Latinoam Nutr., 49 (3): 295

Stern, N. J and Robach, M. C. (2003): Enumeration of Campylobacter species in broiler feaces and corresponding processed carcasses. J. Food Prot., 66: 1556.

Vogel, A. J. (1975): A textbook of practical organic chemistry $3^{\text {rd }}$ ed English language book society and Longman group Ltd., London, pp. 969.

Waldroup, A. L. (1996): Contamination of raw poultry with pathogens. Poult. Sci., 52: 7.

Yang, H.; Yanbin, L. I. and Johnson, M. G. (2001): survival and death of Salmonellae typhimurium and Campylobacter jejuni in processing water and on chicken skin during poultry scalding and chilling. J Food Prot., 64 (6): 770. 